\title{
Macrophage inflammatory protein 1 alpha expression by synovial fluid neutrophils in rheumatoid arthritis
}

The First Department of Internal Medicine, Showa University School of Medicine, Tokyo, Japan

Y Hatano

T Kasama

H Iwabuchi

R Hanaoka

H T Takeuchi

L Jing

M Negishi

H Ide

M Adachi

Department of

Physical Medicine and Rehabilitation, Showa University School of

Medicine, Tokyo, Japan Y Mori

Department of Host Defenses, National Institute of Infectious Diseases, Tokyo, Japan K Kobayashi

Correspondence to: Dr T Kasama, The First Department of Internal Medicine Showa University School of Medicine, $1-5-8$ Hatanodai, Shinagawa-ku, Tokyo 142-8666, Japan.

Accepted for publication 18 January 1999

Yoshimi Hatano, Tsuyoshi Kasama, Hideaki Iwabuchi, Ryosuke Hanaoka, Hiroko T Takeuchi, Lu Jing, Yoshiaki Mori, Kazuo Kobayashi, Masao Negishi, Hirotsugu Ide, Mitsuru Adachi

\begin{abstract}
Objective-To determine the contribution made by synovial fluid (SF) neutrophils to the augmented expression of macrophage inflammatory protein $1 \alpha(M I P-1 \alpha)$ in rheumatoid arthritis (RA).

Methods-Neutrophils were isolated from samples of SF from RA patients and peripheral blood (PB) samples from RA patients and healthy controls. Cell associated MIP-1 $\alpha$ was visualised immunohistochemically, and cell associated MIP-1 $\alpha$ as well as MIP-1a secreted into the SF was assayed by ELISA. Steady state expression of MIP-1 $\alpha$ mRNA was assessed by reverse transcription polymerase chain reaction (RT-PCR).
\end{abstract}

Results-Freshly isolated SF neutrophils contained significantly higher concentrations of both MIP-1 $\alpha$ protein and its transcript than PB neutrophils from either RA patients or healthy controls; incubation in the absence or presence of tumour necrosis factor $\alpha$ for 24 hours resulted in a significant increase in MIP-1 $\alpha$ secretion by RA SF neutrophils compared with neutrophils obtained from either normal PB or RA PB; and expression of MIP- $1 \alpha$ by SF neutrophils was well correlated with both RA disease activity and SF mononuclear cell (MNC) counts.

Conclusion-Expression and secretion of MIP-1 $\alpha$ by SF neutrophils may be indicative of local and systemic inflammation in RA. Moreover, this C-C chemokine may contribute to the recruitment of MNCs from the bloodstream into synovial joints and tissues.

(Ann Rheum Dis 1999;58:297-302)

The progression of rheumatoid arthritis (RA) is characterised by the appearance of inflammatory cells in both the pannus and the joint fluid and by eventual tissue destruction. Various mediators, including inflammatory cytokines and adhesion molecules, have been implicated in the pathogenesis of $\mathrm{RA},{ }^{1-3}$ and specific cell-cell interactions, especially between synovial cells and invading cells, seem to play pivotal parts during the progression of the disease.

Recently identified is a group of factors belonging to a gene superfamily of chemotactic cytokines that share substantial homology, in particular four conserved cysteine amino acid residues. ${ }^{45}$ The C-X-C family of chemokines (for example, IL8, GRO, and ENA-78), in which the first two cysteines are separated by another amino acid residue, is chemotactic for neutrophils and T cells; whereas the C-C chemokine family (for example, macrophage inflammatory protein (MIP)-1, macrophage chemoattractant protein (MCP)-1, and RANTES), in which the first two cysteine residues are in juxtaposition, is chemotactic for monocytes and subpopulations of $\mathrm{T}$ cells. These chemokines seem to play key parts in inflammatory and immune responses mediated by their respective affected cell populations; for instance, release of chemokines from inflammatory cells is a crucial step in the recruitment of the cells required to establish local inflammatory responses (for example, rheumatoid synovitis). Thus, the coordinated production of chemokines and proinflammatory cytokines is likely to be important in the orchestration of the inflammatory responses observed in patients with RA. ${ }^{6}$

Activated neutrophils produce several polypeptide inflammatory mediators: the cytokines, IL1, ${ }^{7-10}$ IL1 receptor antagonist, ${ }^{11}$ IL6, ${ }^{12}$ and tumour necrosis factor (TNF),${ }^{13}{ }^{14}$ and the chemokines, IL8 and MIP-1. ${ }^{15-19}$ Because most infiltrating leucocytes present in the synovial fluid (SF) are neutrophils, and because rheumatoid SF contains a variety of humoral factors produced by monocytes and synoviocytes, neutrophils must be considered to be an important source of the factors mediating RA disease activity. In that context, the aim of this study was to examine the expression of MIP- $1 \alpha$ by SF neutrophils in patients with $\mathrm{RA}$, and to characterise the relation between the concentration of neutrophil derived MIP- $1 \alpha$ and RA disease activity.

\section{Methods}

REAGENT PREPARATION

Recombinant human $\mathrm{TNF} \alpha$ with a specific activity of $1.6 \times 10^{8} \mathrm{U} / \mathrm{mg}$ was purchased from Pepro Tech EC (London, England). Complete medium consisted of RPMI 1640 (Dai-nippon Pharmaceutical Co Ltd, Japan) supplemented with $2 \mathrm{mM}$ L-glutamine, $25 \mathrm{mM}$ Hepes, 100 $\mathrm{U} / \mathrm{ml}$ penicillin, $100 \mu \mathrm{g} / \mathrm{ml}$ streptomycin (GIBCO Laboratories, Grand Island, NY), and $5 \%$ heat inactivated fetal calf serum (GIBCO Laboratories). Monoclonal antibody (MA-291-5) and polyclonal antibody for MIP-1 $\alpha$ were purchased from Austral Biologicals (San Ramon, CA), and R and D Systems Inc, (Minneapolis, MN), respectively. The 

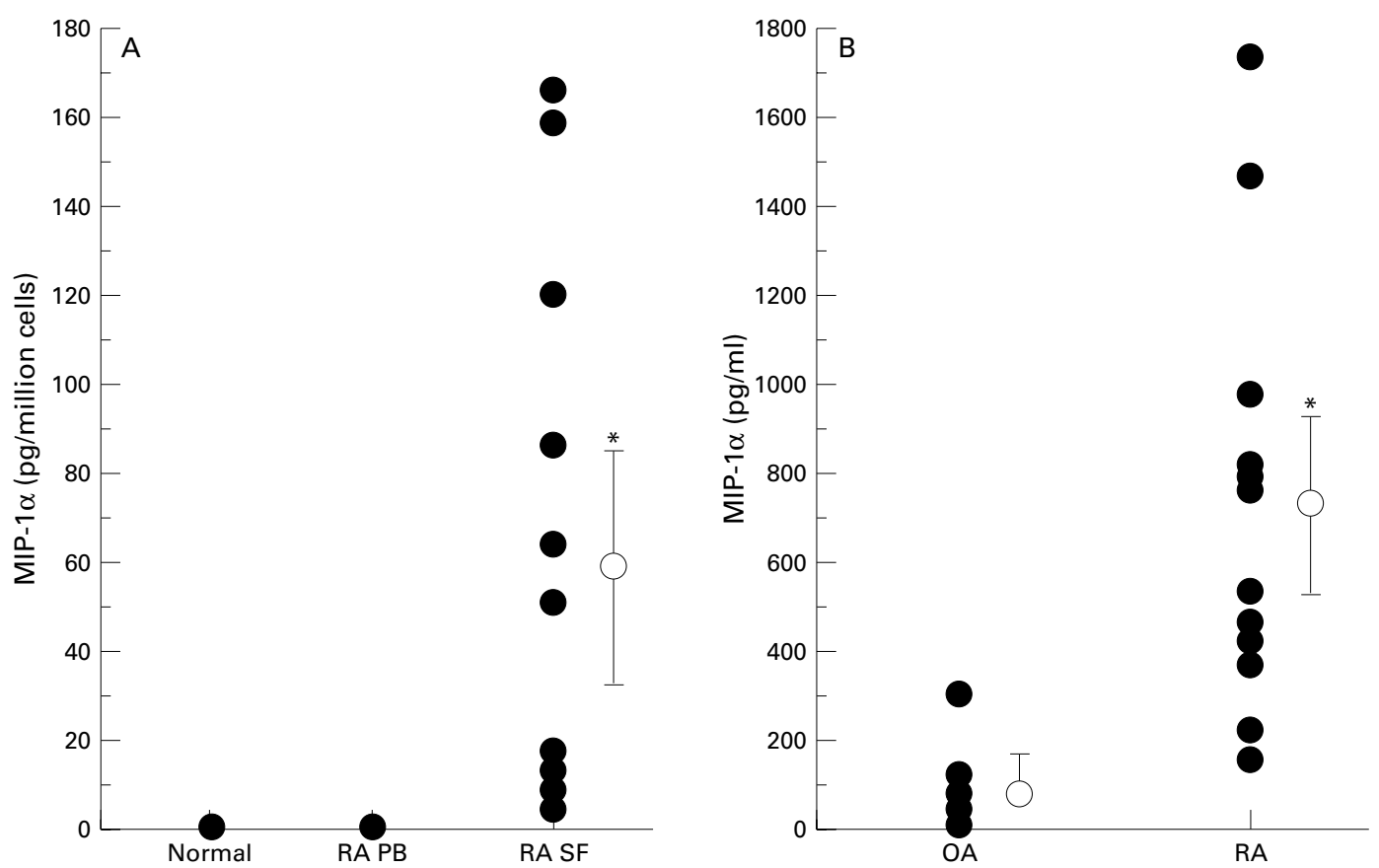

Figure 1 Concentrations of MIP-1a in lysates of freshly isolated neutrophils or in synovial fluids. (A) Neutrophils were obtained from $P B$ of patients with $R A(n=8)$, or healthy normal controls $(n=10)$, and from $S F$ of patients with $R A$ $(n=15)$, then cell associated MIP-1a (pg/million cells) was assessed by ELISA. (B) SF was obtained from patients with $R A(n=15)$ or $O A(n=8)$, then MIP-1a in $S F$ was assessed by ELISA. Data are expressed as the mean $(S E M) .{ }^{*} p<$ $0.05 v R A P B$ or normal $P B(A)$, or $O A(B)$.

antibodies to human MIP-1 $\alpha$ did not cross react with each other, or with other known members of the chemokine family, including RANTES, MCP-1, platelet factor 4, connective tissue activating peptide III, betathromboglobulin, NAP-2, ENA-78, or IP-10. All reagents were tested for endotoxin contamination using a limulus amebocyte lysate test kit (Limulus HS-F test; Wako Chemicals, Tokyo, Japan). The concentration of endotoxin was consistently below $0.03 \mathrm{EU} / \mathrm{ml}$ in all reagents.

ISOLATION AND CULTURE CONDITIONS OF PERIPHERAL BLOOD AND SYNOVIAL FLUID NEUTROPHILS

RA SF neutrophils and MNC, RA peripheral blood (PB) and normal PB neutrophils were

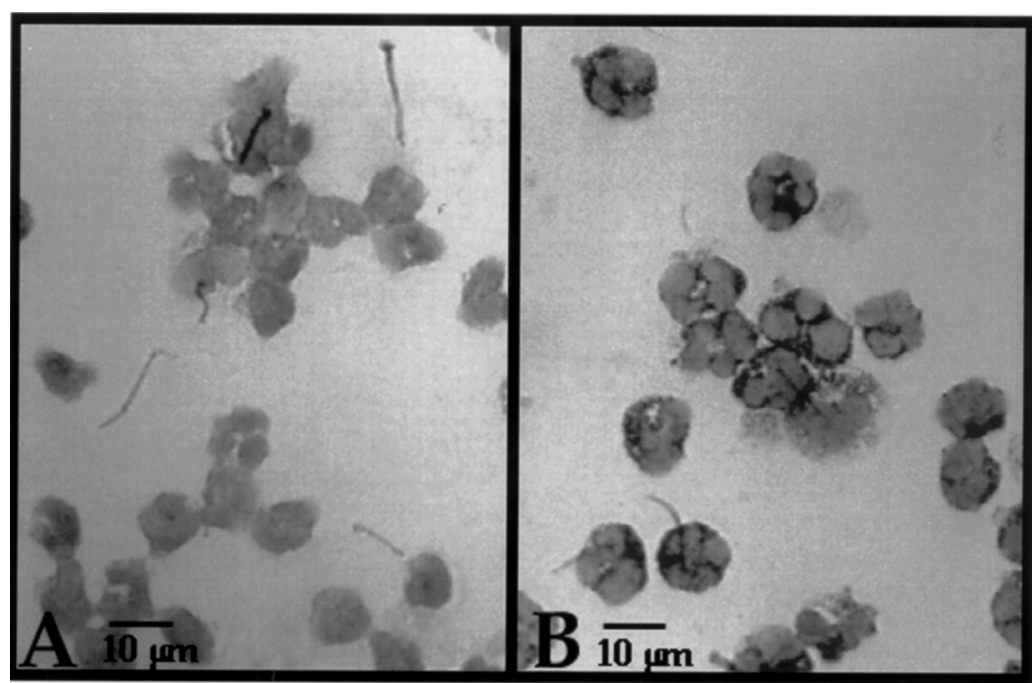

Figure 2 Photomicrograph of the immunohistochemical localisation of antigenic MIP-10 in freshly isolated RA SF neutrophils. (A) Stained by control IgG. (B) Stained by anti-MIP-1a antibody demonstrating the presence of neutrophil associated MIP-1a antigen. obtained from knee puncture of 25 patients (mean age: 56 years, range 36-72, 16 women and nine men) with RA who fulfilled the 1987 ACR criteria, ${ }^{20}$ and from 20 of 25 patients with RA and age and sex matched 15 healthy controls (mean age: 50 years, range 29-69, nine women and six men), respectively, by Ficoll-Hypaque (Pharmacia LKB Biotechnology Inc, Piscataway, NJ), centrifugation, subsequently separated from erythrocytes by lysis of erythrocytes in a solution of $0.15 \mathrm{M} \mathrm{NH}_{4} \mathrm{Cl}$, $0.01 \mathrm{M} \mathrm{NaHCO}_{3}$, and $0.01 \mathrm{M}$ tetra EDTA. Most RA patients were receiving a nonsteroidal anti-inflammatory drug (NSAID) and a slow acting anti-rheumatic drug. Of those receiving a slow acting anti-rheumatic drug, three were taking methotrexate, six were taking D-penicillamine, seven were taking sulphasalazine, and four were taking gold. No patient was receiving either $>5 \mathrm{mg}$ oral prednisolone/day or intra-articular injection of glucocorticoids within one month from SF sample aspiration. The recovered neutrophils were washed three times and resuspended at a density of $5 \times 10^{6}$ cells $/ \mathrm{ml}$ in complete medium. The final cell preparation contained more than $98 \%$ neutrophils by morphology and viability was more than $98 \%$ by trypan blue dye exclusion, and monocyte contamination was below $2 \%$ by non-specific esterase staining. Neutrophils were incubated in the presence or absence of TNF- $\alpha(10 \mathrm{ng} / \mathrm{ml})$ and then cell free supernatants of neutrophil cultures were collected and immediately frozen. To assess cell associated chemokine, neutrophil lysates were obtained by addition of same volume of complete medium to the cells, followed by three freeze/thaw cycles. Furthermore, SF samples were aspirated from patients with RA or osteoarthritis (OA) under aseptic condition, 
A
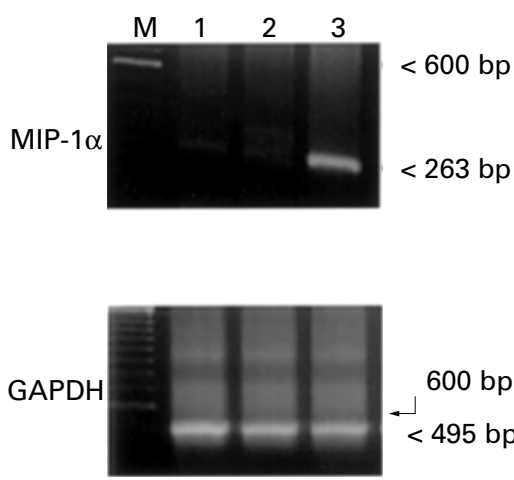

$600 \mathrm{bp}$

$<495 \mathrm{bp}$
B

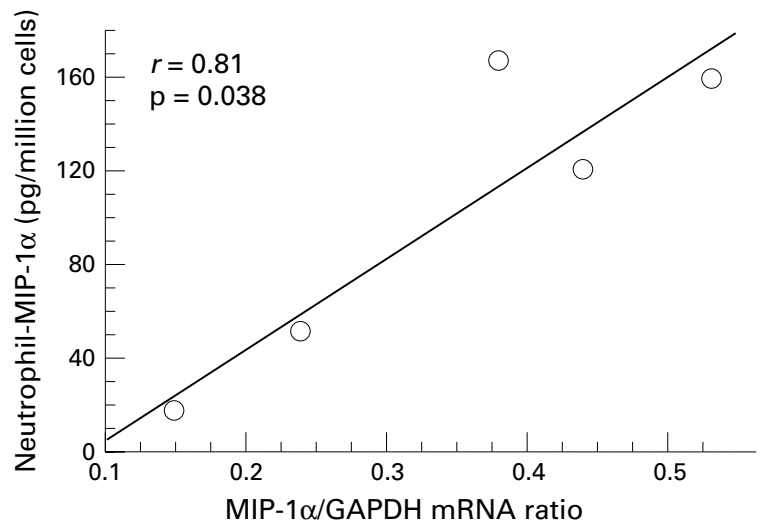

1 Normal PB neutrophils

2 RA PB neutrophils

3 RA SF neutrophils

M 100 bp ladder

Figure 3 Analysis of MIP-1a mRNA in freshly isolated neutrophils obtained from RA SF, RA PB or normal PB using RT-PCR. (A) Representative neutrophil derived MIP-1 a mRNA. GAPDH primers were used as an internal control. M shows molecular weight markers (100 bp ladder); (B) correlation between MIP-1a mRNA concentrations and neutrophil associated MIP-1a protein. MIP-1a mRNA expression was semiquantitated and normalised to GAPDH as the MIP-1a/ GAPDH mRNA ratio. Each point represents an individual patient.
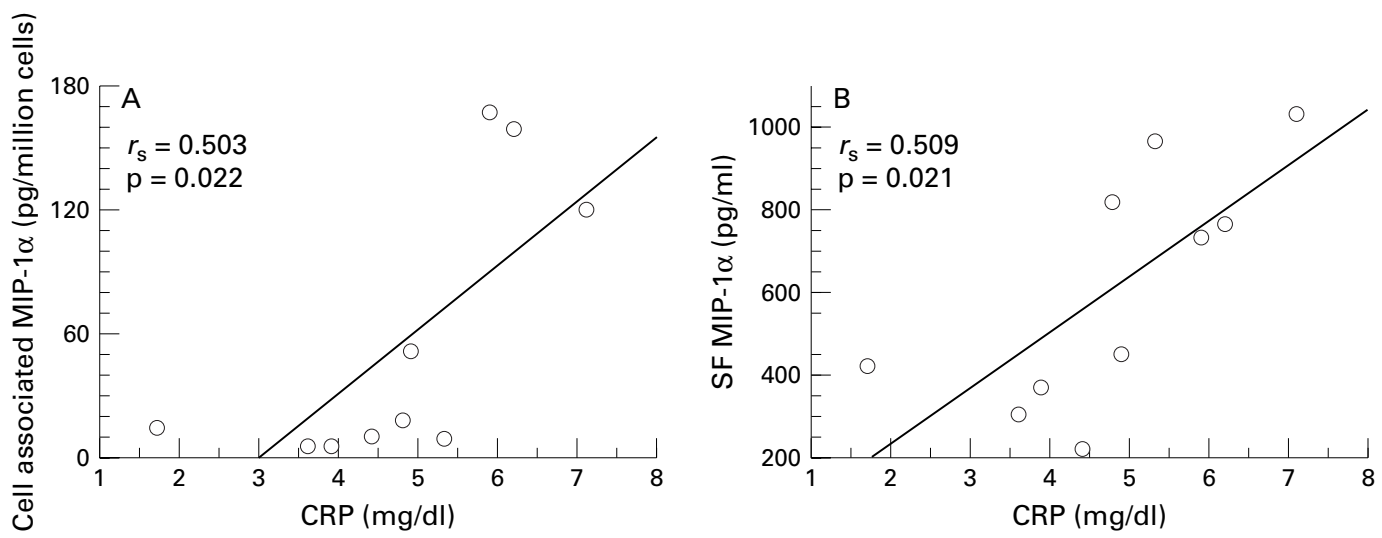

Figure 4 Correlation between SF neutrophil associated (A), or SF MIP-1a (B) and serum CRP concentration. Each point represents an individual $R A$ patient.

and then centrifuged $(2500 \mathrm{rpm}$ for 10 minutes) to remove cell debris. The supernatants were immediately frozen.

$C$ reactive protein (CRP) was measured by the nephelometric standard method.

All human experiments were performed in accordance with protocols approved by the Human Subjects Research Committee at our institution, and informed consent was obtained from all patients and volunteers.

ASSESSMENT OF MIP- $1 \alpha$ CONCENTRATIONS BY SPECIFIC ELISA

Specific neutrophil derived MIP- $1 \alpha$ was quantified using a modification of a double ligand ELISA method, as previously described. ${ }^{21}$ Monoclonal murine antihuman MIP-1 $\alpha$ antibody $(0.5 \mu \mathrm{g} / \mathrm{ml})$ as first antibody and polyclonal rabbit anti-MIP- $1 \alpha$ antibody $(1 \mu \mathrm{g} / \mathrm{ml})$ as second antibody were used. This ELISA method consistently detected MIP- $1 \alpha$ in a linear fashion between $20 \mathrm{pg} / \mathrm{ml}$ and $5 \mathrm{ng} / \mathrm{ml}$.

IMMUNOHISTOCHEMISTRY

Neutrophil derived MIP-1 $\alpha$ was visualised by immunohistochemistry as previously described. ${ }^{17}$ Briefly, neutrophils deposited on a glass slide by using a Cytospin II (Shandon Southern Instruments, Inc, Sewickley, PA). The slides were incubated with polyclonal rabbit anti-MIP- $1 \alpha$ antibody (1:1000 dilution) or pre-immune mouse IgG. Biotinylated rabbit antimouse IgG (1:200; Vector Laboratories Inc, Burlingame, CA) and peroxidase conjugated streptavidin were used as second and third reagents, respectively. The substrate for red colour reaction was 3-amino-9ethylcarbazole in N,N-dimethylformamide (Sigma Chemical Co, St Louis, MO). After rinsing with distilled water, the slides were stained with Mayer's haematoxylin.

ISOLATION OF TOTAL RNA AND REVERSE TRANSCRIPTION POLYMERASE CHAIN REACTION (RT-PCR)

Total cellular RNA from neutrophils was isolated as previously described. ${ }^{17}{ }^{18}$ Briefly, samples were dispersed in a solution of $25 \mathrm{mM}$ TRIS ( $\mathrm{pH}$ 8.0), which contained 4.2 M guanidine isothiocyanate, $0.5 \%$ Sarkosyl, and $0.1 \mathrm{M}$ 2-mercaptoethanol. The RNA was further 


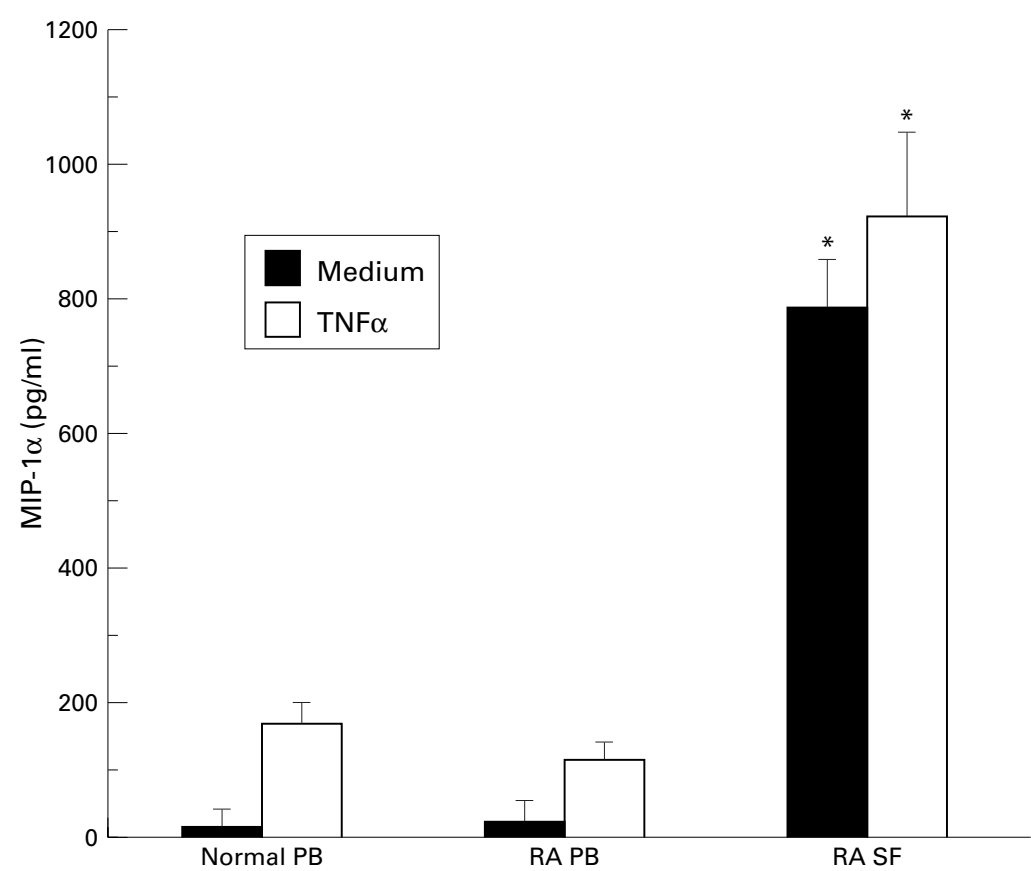

Figure 5 Basal and TNF-a induced MIP-1a secretion by neutrophils obtained from $R A$ $S F, R A P B$, or normal PB. Neutrophils were incubated for 24 hours in the absence

(medium) or presence of TNF- $\alpha(10 \mathrm{ng} / \mathrm{ml})$, after which MIP-1a in the supernatants was assessed by ELISA. Data are expressed as the mean (SEM) of triplicate cultures of three independent experiments. ${ }^{\star} p$ values $<0.05 v$ medium alone.

extracted with the use of chloroform-phenol and alcohol precipitated.

Semiquantitative RT-PCR was performed as previously described. ${ }^{22}$ Briefly, $5 \mu \mathrm{g}$ of total RNA was reverse transcribed into cDNA using M-MLV reverse transcriptase (GIBCO BRL). The PCR reaction was performed with the primers 5'-ACT-GCT-GCC-CTT-GCTGTC-CTC (sense) and 5'-ACT-CAG-CTCCAG-GTC-GCT-GAC (anti-sense) for MIP- $1 \alpha,{ }^{23}$ and 5'-GGC-ATC-CGG-ACGTTC-TAC-GG (sense) and 5'-ATG-GTGAAG-GTC-GGT-GTG-AAC (anti-sense) for GAPDH, ${ }^{24}$ as an internal control. The PCR reactions were separated on $2 \%$ agarose gel containing $0.3 \mu \mathrm{g} / \mathrm{ml}$ of ethidium bromide, and were visualised and photographed using ultraviolet transillumination.

\section{STATISTICAL ANALYSIS}

Data were analysed by Power Macintosh computer using a statistical software package (Statview 4.5; Abacus Concept, Inc, Berkeley, CA) and expressed as the mean (SEM). Data were evaluated by Mann-Whitney test and the

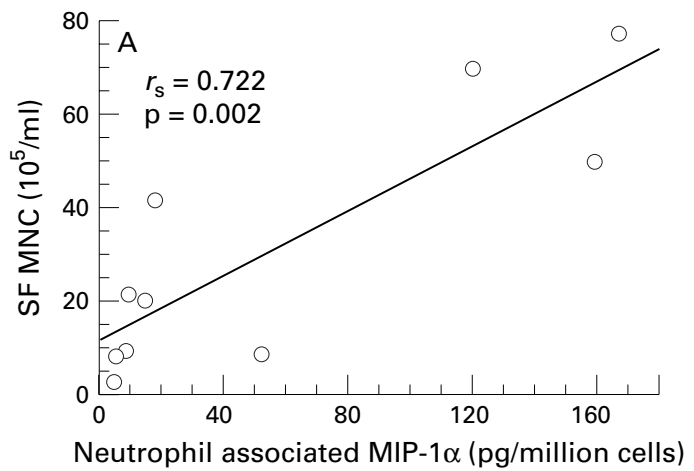

Spearman rank correlation coefficient where appropriate. A p value of less than 0.05 was considered significant.

\section{Results}

EXPRESSION OF CELL ASSOCIATED MIP- $1 \alpha$ BY ISOLATED NEUTROPHILS AND CONCENTRATIONS OF MIP- $1 \alpha$ IN SYNOVIAL FLUID

We hypothesised that the neutrophils present in the SF of RA patients (RA SF neutrophils) are an important cellular source of the C-C chemokine, MIP-1 $\alpha$. To test this hypothesis, we first determined whether freshly isolated neutrophils contained MIP-1 $\alpha$ protein. Neutrophils were isolated from the $\mathrm{PB}$ of patients with RA, from the PB of healthy control subjects, and from the SF of patients with RA. Cell associated MIP- $1 \alpha$ was then assayed by ELISA. As shown in figure $1 \mathrm{~A}$, freshly isolated RA SF neutrophils contained substantial quantities of MIP-1 $\alpha$ (58.6 pg/million cells), whereas MIP- $1 \alpha$ was undetectable in neutrophils isolated from PB. Moreover, in agreement with previous reports (fig 1B), ${ }^{25}$ concentrations of MIP- $1 \alpha$ in the SF of patients with RA $(729 \mathrm{pg} / \mathrm{ml})$ were significantly greater than those in the SF of patients with OA $(63 \mathrm{pg} / \mathrm{ml})$.

The specific cell type expressing MIP-1 $\alpha$ protein was verified immunohistochemically: freshly isolated RA SF neutrophils were positively labelled by anti-MIP- $1 \alpha$ antibodies (fig 2B). RA SF neutrophils exposed to preimmune control IgG (fig 2A) exhibited no MIP-1 $\alpha$ labelling, nor did PB neutrophils obtained from healthy controls and RA patients (data not shown).

Consistent with the expression of MIP-1 $\alpha$ protein, PT-PCR revealed substantial steady state expression of MIP-1 $\alpha$ mRNA in freshly isolated RA SF neutrophils; indeed, there was a significant correlation between the levels of MIP- $1 \alpha$ transcript and the levels of cell associated MIP- $1 \alpha$ protein (fig $3 \mathrm{~A}$ and B). MIP-1 $\alpha$ mRNA was not detected in PB neutrophils.

The acute phase response, as measured by CRP concentration, is commonly used in clinical practice to monitor RA disease activity. Increased CRP concentrations are indicative of disease progression and the absence of a positive response to treatment. We, therefore, examined the extent to which disease activity correlated with MIP-1 $\alpha$ concentrations in RA SF neutrophils and in the SF of RA patients.

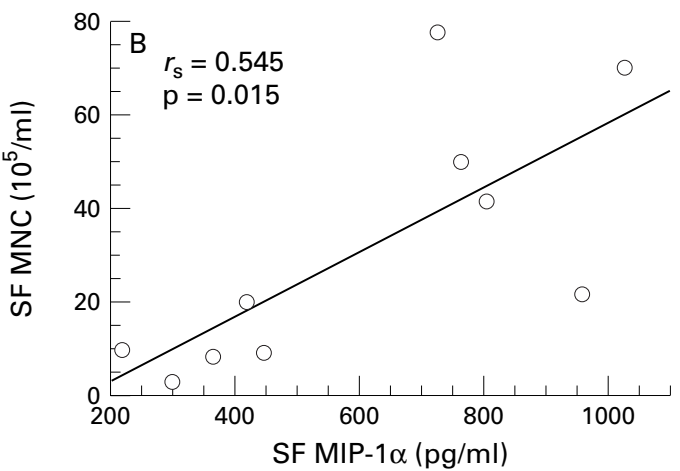

Figure 6 Correlation between SF neutrophil associated (A) or SF MIP-1a (B) and SF MNC counts. Each point represents an individual $R A$ patient. 
Figure 4 shows that there was a significant correlation between serum CRP and both cell associated MIP- $1 \alpha$ levels $\left(r_{\mathrm{s}}=0.503, \mathrm{p}=0.022\right)$ and MIP- $1 \alpha$ concentrations in SF $\left(r_{\mathrm{s}}=0.509\right.$, $\mathrm{p}=0.021)$. In contrast, there was no correlation between MIP- $1 \alpha$ and CRP concentrations in either SF or serum from OA patients $\left(r_{\mathrm{s}}=0.003\right.$, $\mathrm{p}=0.903$; data not shown); nor was there a correlation between MIP- $1 \alpha$ levels and the use of NSAIDs, oral or intra-articular glucocorticoids, or slow acting antirheumatic drugs (data not shown).

EFFECTS OF TNF- $\alpha$ ON THE SECRETION OF NEUTROPHIL DERIVED MIP- $1 \alpha$

We next examined the effects of TNF- $\alpha$ on MIP- $1 \alpha$ secretion. In the absence of TNF- $\alpha$, RA SF neutrophils secreted $809 \mathrm{pg} / \mathrm{ml}$ of MIP-1 $\alpha$ (fig 5) over the course of a 24 hour incubation period. Neutrophils obtained from normal and rheumatoid PB, by contrast, secreted only $22 \mathrm{pg} / \mathrm{ml}$ and $29 \mathrm{pg} / \mathrm{ml}$, respectively, over the same period. Twenty four hours in the presence of TNF- $\alpha$ increased MIP- $1 \alpha$ secretion from all three neutrophil populations; none the less, secretion from RA SF neutrophils remained significantly higher (928 $\mathrm{pg} / \mathrm{ml})$ than from normal $(174 \mathrm{pg} / \mathrm{ml})$ or rheumatoid PB neutrophils $(131 \mathrm{pg} / \mathrm{ml})$.

CORRELATION BETWEEN MONONUCLEAR CELL INFILTRATION OF THE SF AND THE LEVELS OF NEUTROPHIL ASSOCIATED AND SECRETED MIP- $1 \alpha$ MIP- $1 \alpha$ is thought to be chemotactic for monocytes and subpopulations of T cells. ${ }^{26} \mathrm{We}$, therefore, examined the relation between the numbers of MNCs present in SF and the concentrations of neutrophil associated and secreted MIP-1 $\alpha$. As shown in figure 6, there was a significant correlation between MNC counts and both neutrophil associated MIP-1 $\alpha$ $\left(r_{\mathrm{s}}=0.722, \mathrm{p}=0.002\right)$ and the MIP- $1 \alpha$ concentration in the SF $\left(r_{\mathrm{s}}=0.545, \mathrm{p}=0.015\right)$.

\section{Discussion}

MIP- $1 \alpha$, which is a member of the C-C chemokine family, is a lipopolysaccharide (LPS) inducible, heparin binding polypeptide first isolated from LPS treated murine RAW 264.7 cells. ${ }^{26-28}$ In a recent study, we showed that MIP- $1 \alpha$ was present in arthritic joints during the evolution of murine collagen induced arthritis (CIA), an experimental model of RA; moreover, exacerbation of CIA could be prevented by administration of neutralising anti MIP- $1 \alpha$ antibodies. ${ }^{22}$ This strongly suggests that MIP- $1 \alpha$ plays a pivotal part in the development of RA.

Chemokines (for example, IL8, MCP-1, and MIP-1 $\alpha$ ) are readily detectable in rheumatoid $\mathrm{SF}$, and their values correlate with RA disease activity ${ }^{25}{ }^{29-32}$ These findings led us to speculate that the presence of chemokines in rheumatoid SF might, in part, depend on SF neutrophils, which are the principal cell type accumulated in the SF of RA patients. The main finding of this study was that freshly isolated RA SF neutrophils express significant quantities of MIP-1 $\alpha$ and its transcript, and that this expression was well correlated with RA disease activity. In addition, secretion of MIP- $1 \alpha$ was significantly augmented by $\mathrm{TNF}-\alpha$, suggesting that in vivo, RA SF neutrophils are primed by exposure to mediators (for example, $\mathrm{TNF}-\alpha$ ) within rheumatoid joints. Clinically, synovial inflammation in RA is characterised by marked infiltration by MNCs and neutrophils into the synovial space and into synovial tissue. Although MNCs isolated from the SF of patients with RA contained higher levels of MIP- $1 \alpha$ (325.7 (111.9) pg/million cells; data not shown) than did RA SF neutrophils (58.6 (20.2) pg/million cells), the latter probably contribute more significantly to the increased MIP- $1 \alpha$ levels in RA, because neutrophils are generally present in much larger numbers. In addition, we observed that both RA SF neutrophil associated MIP-1 $\alpha$ and secreted MIP-1 $\alpha$ were well correlated with the numbers of MNCs present in the rheumatoid SF. Thus, it seems probable that increased concentrations of neutrophil associated and secreted MIP- $1 \alpha$ may be indicative of both local and systemic inflammation in RA, and that MIP- $1 \alpha$ may stimulate recruitment of MNCs from the bloodstream into synovial joints.

In conclusion, the data presented here shed new light on the function of SF neutrophils in perpetuating inflammation in RA. Increased understanding of the role of SF neutrophils in RA may provide the basis for a new approach to therapeutic immunointervention in the disease process, whereby activated neutrophils and neutrophil derived MIP- $1 \alpha$ in the synovial space are targeted.

Funding: this study was supported, in part, by Uehara Memorial Foundation, Research Promotion of Emerging and Reemerging Infectious Diseases (Ministry of Health and Welfare), Sasakawa Memorial Foundation, and The United States-Japan Cooperative Medical Science Program against Tuberculosis and Leprosy.

1 Harris ED Jr. Rheumatoid arthritis: pathophysiology and implications for therapy. N Engl J Med 1990;322:1277-89. Sewell KL, Trentham DE. Pathogenesis of rheumatoid arthritis. Lancet 1993;341:283-6.

3 Kunkel SL, Lukacs NW, Kasama T, Strieter RM. The role of chemokines in inflammatory joint disease. J Leukoc Biol of chemokines in

Rollins BJ. Chemokines. Blood 1997;90:909-28.

5 Luster AD. Chemokines-chemotactic cytokines that mediate inflammation. N Engl J Med 1998;338:436-45.

6 Arend WP, Dayer JM. Cytokines and cytokine inhibitors or antagonists in rheumatoid arthritis. Arthritis Rheum 1990; 33:305-15

7 Tiku K, Tiku ML, Skosey JL. Interleukin 1 production by human polymorphonuclear neutrophils. J Immunol 1986; 136:3677-85.

8 Lindemann A, Riedel D, Oster W, Meuer SC, Blohm D, Mertelsmann RH, et al. Granulocyte/macrophage colonystimulating factor induces interleukin 1 production by human polymorphonuclear neutrophils. J Immunol 1988; 140:837-9.

9 Marucha PT, Zeff RA, Kreutzer DL. Cytokine regulation of IL-1 $\beta$ gene expression in the human polymorphonuclear IL-1 $\beta$ gene expression in the human po

10 Lord PCW, Wilmoth LMG, Mizel SB, McCall CE. Expression of interleukin- $1 \alpha$ and $\beta$ genes by human blood polymorphonuclear leukocytes. J Clin Invest 1991;87: $1312-21$

11 McColl SR, Paquin R, Menard C, Beaulieu AD. Human neutrophils produce high levels of the interleukin 1 receptor antagonist in response to granulocyte/macrophage colony-stimulating factor and tumor necrosis factor $\alpha$. J Exp Med 1992;176:593-8.

12 Cicco NA, Lindemann A, Content J, Vandenbussche P, Lubbert M, Gauss J, et al. Inducible production of interleukin-6 by human polymorphonuclear neutrophils: Role of granulocyte-macrophage colony-stimulating facto 3 Lindemann A, Riedel D, Oster W, Ziegler-Heitbrock HW, Mertelsmann R, Herrmann F. Granulocyte-macrophage colony-stimulating factor induces cytokine secretion by human polymorphonuclear leukocytes. J Clin Invest 1989 83:1308-12. 
14 Dubravec DB, Spriggs DR, Mannick JA, Rodrick ML. Circulation of human peripheral blood granulocytes synthesize and secrete tumor necrosis factor $\alpha$. Proc Natl Acad Sci USA 1990;87:6758-61.

15 Bazzoni F, Cassatella MA, Rossi F, Ceska M, Dewald B, Baggiolini M. Phagocytosing neutrophils produce and release high amounts of neutrophil-activating peptide 1/Interleukin 8. J Exp Med 1991;173:771-4.

16 Strieter RM, Kasahara K, Allen RM, Standiford TJ, Rolfe derived interleukin-8. Am J Pathol 1992:141:397-407.

17 Kasama T, Strieter RM, Standiford TJ, Burdick MD, Kunkel SL. Expression and regulation of human neutrophilderived macrophage inflammatory protein $1 \alpha$. J Exp Med 1993;178:63-72.

18 Kasama T, Strieter RM, Lukacs NW, Burdick MD, Kunkel SL. Regulation of neutrophil-derived chemokine expression by IL-10. J Immunol 1994;152:3559-69.

19 Strieter RM, Kasahara K, Allen R, Showell HJ, Standiford TJ, Kunkel SL. Human neutrophils exhibit disparate chemotactic factor gene expression. Biochem Biophys Res Commun 1990;173:725-30

20 Arnett FC, Edworthy SM, Bloch DA, McShane DJ, Fries JF, Cooper NS, et al. The American Rheumatism Association 1987 revised criteria for the classification of rheumatoid arthritis. Arthritis Rheum 1988;31:315-24.

21 Kasahara K, Tobe T, Tomita M, Mukaida N, Shao-Bo S, Matsushima $\mathrm{K}$, et al. Selective expression of monocyte Matsushimi $\mathrm{K}$, et chemotactic and activating factor/monocyte chemoattractant protein 1 in human blood monocytes by Mycobacterium tuberculosis. J Infect Dis 1994;170:1238-47.

Kasama T, Strister RM, Lukacs NW, Lincoln PM, Burdick $\mathrm{MD}$, Kunkel SL. Interleukin-10 expression and chemokine regulation during the evolution of murine type II collageninduced arthritis. J Clin Invest 1995;95:2868-76.

23 Zipfel PF, Balke J, Irving SG, Kelly K, Siebenlist U. Mitogenic activation of human T cells induces two closely related genes which share structural similarities with a new family of secreted factors. J Immunol 1989;142:1582-90.
24 Dugaiczyk A, Haron JA, Stone EM, Dennison OE, Rothblum KN, Schwartz R. Cloning and sequencing of a deoxyribonucleic acid copy of glyceraldehyde-3-phosphate dehydrogenase messenger ribonucleic acid isolated from chicken muscle. Biochemistry 1983;22:1605-13.

25 Koch AE, Kunkel SL, Harlow LA, Mazarakis DD, Haines GK, Burdick MD, et al. Macrophage inflammatory protein-1 $\alpha$ : A novel chemotactic cytokine for macrophages in rheumatoid arthritis. J Clin Invest 1994;93:921-8.

26 Wolpe SD, Cerami A. Macrophage inflammatory proteins 1 and 2 : members of a novel superfamily of cytokines. FASEB J 1989;3:2565-73.

27 Davatelis G, Tekamp-Olson P, Wolpe SD, Hermsen K, Luedke C, Gallegos C, et al. Cloning and characterization of a cDNA for murine macrophage inflammatory protein (MIP), a novel monokine with inflammatory and chemokinetic properties. J Exp Med 1988;167:1939-44.

28 Wolpe SD, Davatelis G, Sherry B, Beutler B, Hesse DG Nguyen HT, et al. Macrophages secrete a novel heparinbinding protein with inflammatory and neutrophil chemokinetic properties. J Exp Med 1988;167:570-81.

29 Peichl P, Ceska M, Effenberger F, Haberhauer G, Broell H, Lindley IJD. Presence of NAP-1/IL-8 in synovial fluids indicates a possible pathogenic role in rheumatoid arthritis. Scand J Immunol 1991;34:333-9.

30 Koch AE, Kunkel SL, Burrows JC, Evanoff HL, Haines GK, Pope RM, et al. Synovial tissue macrophage as a source of the chemotactic cytokine IL-8. J Immunol 1991, 147:2187-95.

31 Koch AE, Kunkel SL, Harlow LA, Johnson B, Evanoff HL, Haines GK, et al. Enhanced production of monocyte chemoattractant protein-1 in rheumatoid arthritis. J Clin Invest 1992;90:772-9.

32 Akahoshi T, Wada C, Endo H, Hirota K, Hosaka S, Takagishi K, et al. Expression of monocyte chemotactic and activating factor in rheumatoid arthritis: Regulation of its production in synovial cells by interleukin-1 and tumor necrosis factor. Arthritis Rheum 1993;36:762-71. 